であつ旡っそ5すると（2）式と（3）式との間に は，60 $\mathrm{C}^{\circ}$ の溫度差が岁つをことになる。そこですず これら二つの化學式を基として，この間を連絡づける 樣にいろいろと化學式を變化してみると次の樣な熔倒 軟化溫度が確められを。

$\left.\left.\begin{array}{lllll}0.3 & \mathrm{~K}_{2} \mathrm{O} \\ 0.7 & \mathrm{CaO}\end{array}\right\} \begin{array}{llll}0.4 & \mathrm{Al}_{2} \mathrm{O}_{3} \\ 0.1 & \mathrm{Fe}_{2} \mathrm{O}_{3}\end{array}\right\} 4 \mathrm{SiO}_{2} \cdots\left(1170^{\circ} \mathrm{C}\right) \cdots(4)$

$\left.\left.\begin{array}{lll}0.3 & \mathrm{~K}_{2} \mathrm{O} \\ 0.7 & \mathrm{CaO}\end{array}\right\} \begin{array}{lll}0.45 & \mathrm{Al}_{2} \mathrm{O}_{3} \\ 0.05 & \mathrm{Fe}_{2} \mathrm{O}_{3}\end{array}\right\} 4 \mathrm{SiO}_{2} \cdots\left(1190^{\circ} \mathrm{C}\right) \cdots(5)$

ここで初めて 4 種の基碟的な調合物が得られを。ゼ ーゲルはこの低溫度の（3）式を1番と名づけ，（4) 式を2 番, (5) 式を 3 番, 最初説明した（2）式 を4番として體系づけることにした。すなわら SKK(1) 1 番といらのはゼーゲルコーン1番とい5ことで, SK はその頭文字をとつをものである。この樣にして 順次乥の熔倒溫度学確めて，ついに 1150 $1850^{\circ} \mathrm{C} の$ 36種すなわち SK1 番から 36 番までを完成した。 これがゼーゲルによるゼーゲルコーンの製造された歴
史で岕る。しかし科學怯進歩する。實際に使用すると

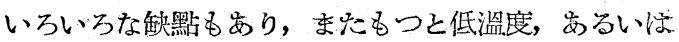
高堽度のものが必要となつて, それらが追加されるこ とになつ恕。このときのものは現在のゼーゲルコーン と成分的に相當相違しているので舊制ゼーグルコーン とよばれている。しかし以上の樣なゼーゲルの努力と 創造に對しては，心から尊敬の念を拂わなければなら ない。次に气追加と改正の歴史について學ぶことに しょ5。

\section{訂 正}

前號第 321 項の第 18 圖酸素アセチレン炎の各種の 狀態の説明を゙下記の通り訂正い比します。

第 18 圖 (a) 酸素の多い完全燃燒をした酸化 炎である。(b) は中性焱である。(c) はアセチレン 瓦斯の多い還元炎である。

(1) SK は Seger Cone，すなわち Seger Ḱegelの頭交字

\section{爐 邊 \\ 隨 想}

\section{氣象豫報の六感}

會長 德 根 吉一郎

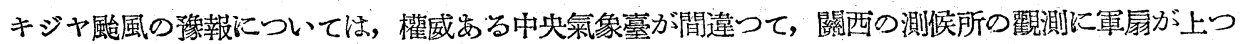
た。ことに四國の劍山測候所が過去の賽樍飞物を言わせて, キジャ颱風の西來説をいち早く發表し，

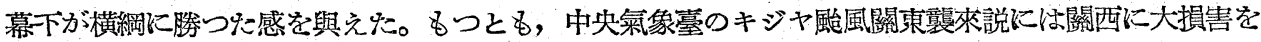

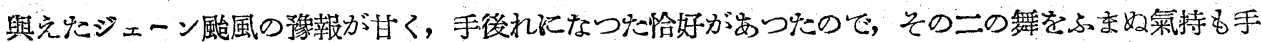

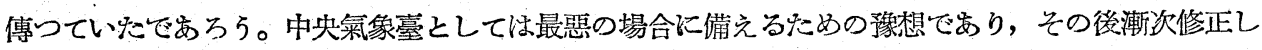
たことは，必ずしも權威を失隥するるのではない。だ゙全國的材料学綜合判椹する中央氣象臺が，地 方測候所の觀測も輕視しないととが大切で岀ろう。

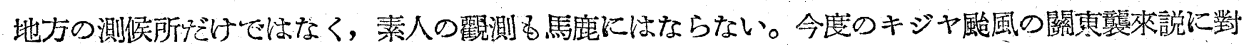
し，二人の素人が私にその反對擎測を述べていた。それは盲腸を切開手術した人であつたが，その人 が言らには『暴風雨の前には私の賃跡が必らずうずく，ところがキジヤ風風の矠報が出つても，少し

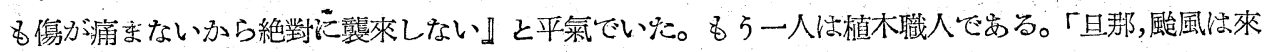
ませんよ，蜂が木の高いところに蕞をかけていすすよ。われわれ蚛間では，蜂が高い木の上汇条をか

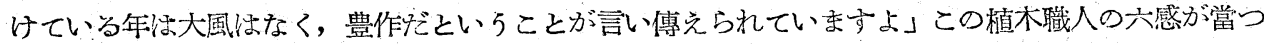
导のである。

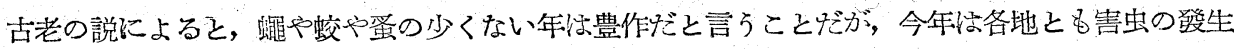
の少くないこと私共のひとしく實驗しているところだが，今年然なるほどたしか澧作型であ る。前述の植木職人の言つ䗋の巢と大風の關係も，これと似ている。地震の前に结鳥が先へ飛んて

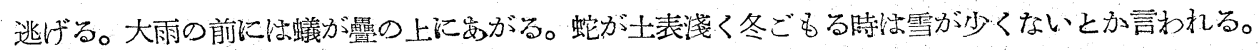

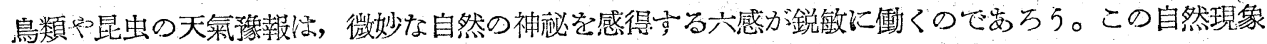
を古老の長年の體驗によつて言傳えられているのは，必しも荒唐鎜稳とは言えない。その奥に科學的 原理がひそんでいる考えられる。 


\section{産 業 經 濟 解 說}

\section{事變後の日本經濟はどう展開しゅくか}

\section{(1)}

今後の日本經濟はど5動いてゆくか。景氣はよくな るか。その時機はいかかこの質問に對し確信をるつ

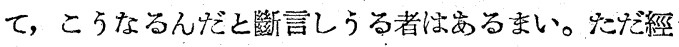
濟界を動かしている幾つかの前提條件が，このオ向に 進むとすれば，經濟界经かくならざるを得ないであろ 5し，それらの條件が，この程度現れるとすれば，經 濟はこの程㡲好轉する管であるという見透しはつけら るので览る。從つて經濟觀測には，まづ前提條件の觀 測が先決問題である。

乙からな゙現在日本經濟を動かしている基本條件心何 か。それ惊米り關係で㐫り，朝群事變で岁る。事變後 の日本經濟々前途樂觀視が約束されているょらである テそが，これには，朝鮮の戰局が國連側に有利に展開す ること。朝鮮の戰後復與が起り, これに物資需要が増 大してゆくとい5前提條件に立つた觀測で岀る。不幸 にして萬一,これらの基礎棥件が崩れることが㐫れば， 結論す根本的に變つてくる譯染。よつて我々は, 日本 經濟の將來娄打診するに當つて, をづ朝鮮事變の見透 しから始めよ5。

周知の如く南鮮の戰線膠着狀態 8 月から 9 月なか 㥙をで續いタ。兩軍の兵力を比較するに，北鮮軍10ケ 師團から 15 ケ師團とみられ，兵䝿 15 萬から 25 萬人 とみられる。これに對し, 國連軍必 5 ケ師團で 9 萬程

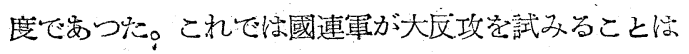
出來ない。米國は前大戰の經驗から考えても, 決して 小手先の相撲はとらない。量的にも質的にも, 絶對優位. の體勢をとつて始めて攻勢にでるのが定跡である。い わゆる横綱相撲である。朝鮮戰線にもこの戰法がとら れている。

從つて, 國連軍の反闑作戰が大規模に展開されるに は，をづ兵力量の補強が必要となる。これがケめ米國

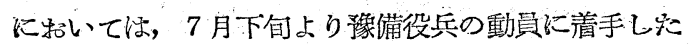
が，これが出動準備をなし，朝鮮戰線に配置されると きこ合，國連軍の活潑なる反警が始をるとみてよい。
ダイヤモンド社社長 加 藤 一

寸でに 9 月15日には，仁川，群山等に上陸作戰が行わ れた。これは米軍の補給が著しく強化された證左であ る。國連軍の大反攻作戰が，開始されたとみてよい。 かくの如く戰局は國連軍に有利化してきた。こうな ると米ソの外公的な動きも, 當然今後は變轉しゆく䈏 である。北鮮軍が絶對的に優位な情樊にある間は，ソ 聯も強硬狀態度を改めないが，米軍の攻勢樴烈化する こととなれば, 漸次妥協的態度に出でざる学得なくな る。ことに, 米國の軍㱬が着々と軌道にのつてくれ ば, ソ連としても，第三次大戰の勃發を欲せざる現在 に物いて度，妥協的方策をるつて大戰の突入学避ける 筈である。

何人が考えても，第三次大戰は長期戰である。長期 戰となれば, 結局は兩國がもつ經濟力の強弱が最後の 勝負を決するものである。然るに米りの經濟力は，現 在のところ相當大きなひらきが岕る。昨年の生産高か ら比較しても原油治物いて10對 1 , 鋼材, 石炭, 電力 も 4 對 1 乃至は 3 對 1 の程底に過ぎない。これでは長 期戰で勝利を5ること蜼しい。從つてり連の目標 は, この生産力を米國の生産水準にまで向上させるこ とである。それまでの時を稼ぐ。從つてその間は，極 力米或の國力を消耗させながら，大戰の勃發心避けせ いといらのが狙いである。それがけめ米國の軍擴が軌

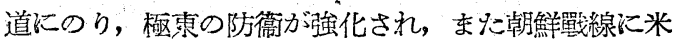
軍の本格的反擊が展開されてくると, ソ連としては當 然妥協的態度に轉換してゆくであ万弓。かくみれば， 來春頃から漸次平和狀態が現れてくる䈍である。

\section{(2)}

上述の如く朝鮮事變は，9月牛にて翏着狀態を脫 し, 米軍の反熬開始, 今後戰局の有利展開となつて·く れ代, 來春頃から政治的妥協が始をり, 極東の險惡化 は一應解消する。こういう豫想を前提として, 日本經 濟一の影響を考えてみる。

朝鮮事變による特需の發生は,デフレ恐慌で悲鳴を 
あげてい\%日本經濟染蕉生させう。所謂特需景氣であ る。その金額は，GHQの發表によれば7月末まで 大體 3,000 萬弗，100 億圓とい5。この調子で特需が 續け壮，年内に 600 億圓といら龙大なものとなら5。 だが現在の戰况と既に述べた今後の戰況矠想から推察 す衿ば，特需景氣を過大視するてとは危險である。 8 ， 9 月は，釜山を中心として僅か 50 キロの狹少な地域 に, 橋頭堡を保持するのが勢一杯であうら。大消耗戰 はめるむいし， 7 月頃の如き物資の大調澾るないであ ろらからこの 2 ケ月間の特需は當然降下するとみるべ きである。

而して調達價格は最近著しく安くなのつてきた。7 月 27 日の周東安压官と總司令部經濟科學局首腦者 との會見で, 經濟科學局側から納入敒格の點にて警告 をらけを事は重視すべきである。刨ち「日本業者の中 には, 米國側の買付に對して, 不當な顀格で應ずる者 がある。連結用パイプを國内價格の 4 倍で賣付けな例 がある。もし今後もこのような不當な偩格を陧える者 があれば; 日本商品の買付けを取止め，ずて米本國 で買付けることにする」と斷言されたといら。火事泥 的な儲は許されるものでない。現實に最近は著しく債 格の低下をみせている。海運界を久ても一眭, 36萬噸 の傭船が岀つたものが,いをは17萬瀬と牛減し,しかも 啸船料は, 今ま 12,000 噸級注瀬當り 1 弗 63 仙, 小 型船になるにつれ，料金怺進的に高くなつていた。 それが7月 23 日より1弗50仙均一と, 著しい引下 げをみをのである。土囊用麻袋にしても, 事變直後は 27 仙で買付けられたものが，14 仙をで引下げられて いる。

かように 7 月初頃の特需は緊急調临であり, 時間的 にみて米國より補給しえないるのは, 極力日本商品て 補充した譯だ。從つて價格も不當に高いものも市つた が, 戰線が膠着し，補給時期にもゆとりが出來てくる と, 特需も當然計畫的とならざるを得ない。價格の點 から, 或は生産量の點からみて, 米本國から, 或は西 歐から求めたのが有利であると考えれば, 註文先を變 更してゆく。要するに特需景氣は, 過渡期 現象であ り, 事變似よる第一次需要であり, 米國が本格的な補 給戰の體制を確立するにつれ，漸裁されてゆく性質の ものである。現在はやくも漸減の過程に入りつつあり とみるべき非。

しからば今後の日本經濟はどら進展するか。大局か
らみて我々はわが經㵒の前途を樂觀する。なぜとなら ば, をとえ, 特需景氣は，8，9月に特いて低調化し ても, これに代る長斯的性格をるつ好材料が起つてく る筈である。

その第一は, 朝鮮復薈と民生安定に要する物資需要 の增大である。米軍の反繁作戰が成功した䁱において

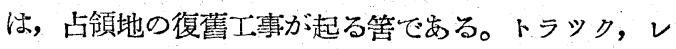
ール, 衣料品, 醫藥品, セメント, 木材, 食料品の如 き一般需要が増大するにちがいない。可論，それとて も國際價格を無視して, 何でも日本から買上げるとは 考えられないが, 亦る程度の需要增は豫想してよい。 もつともこれが需要が現實化してくるのは來春頃とみ るべきである。

第三の好材料は，世界的な軍撗に上る好影響で嵓 り, これ认朝鮮戰況の如何にかふわらず, 現在も現れ てをり，今後も起きてくる影響である。試多に米國軍 事費の膨脤を久るに，本年度通常軍事費 146 億弗，そ れに追加 105 億弗, さらに米國の對外軍事援助費52億 弗，合計 303 億といら龙大な額で岕る。これに對抗し てソ連も軍事費を增加した。最高會䉝で決定した額は 794 億ルーブルの豫算，これを公定レートで换算すれ ば 190 億弗となる。これら兩國の軍擴競争によつて, それぞれの金下にある諸國も軍撗に乘り出し, 米》關 係國の軍事費合計以 615 億弗に達する。前年度の 420 億弗に較ぶれば $46 \%$ 經費膨脤であり, 平常時に特 いてかつて見ざる龙大な數字となる。

かかる軍撗競学の擴大以必然的に重要物資の不足時 代を出現さす。トルーマンは,必要な場合, 不足物資を 軍用に優先的に割當てる權限を議會に要求したことか ら推察しても, 物資不足時代の到來が懸念されている から芯。第一次に不足物資として統制完必要とするす のとして, 鐵鋼, 銅, 亞鉛, 錫, アルミニューム, 化 學藥品, 木材, ゴム, 羊毛, 石油等が一般に敄想され ている。その結果として軍需原料の大量買付が世界的 に起る。重要物資の價格滕貴となつてくる。さらに軍 撗競爭保やがて平和産業の生産を壓迫し, これが品不 足, 價格の上昦学招來して，一般物價の水準学押上げ る作用をなしてくる。これが日本經洬に好影響をすた らす筈である。

第三の好材料惊わが輸出伸展が期待されることだ。 本年 1 月の輸出契約をみるには 4200 萬弗, それが 6 月 には 6,300 萬弗に, さらに 7 月には 7,424 萬弗之鰻上 
りに増大してきた。この譑子でゆけば，輸出年間 8 億 弗の達成马可能をごとい: 5 見方马ある。輸出8 億弗とい 5 のは，昨年實績の 5 億弗に對して約 $60 \%$ 增に當る。 本年上牛期の大藏省税關部の船積實績額が 3 億 2,500 萬弗であるところからみて，この見才心あえて誇大な ものではない。師ち今啳のわが輸出面に現れてくる好

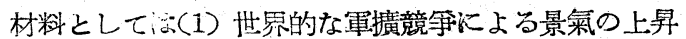
と買漁りに伴 5 輸出品價格の上昇，(2) 米國の積極的 買付けに上るアジア地域の弗不足の緩和，(3) 日本船 船の就航による運賃の輕減がある。

各國の物顀昂騰宗，ポンド切下げ以來，とかく割高 と非難されていけわが輸出品僓格てさえあまり目立た なくなつ程であり，物によつてい割安となりつつ市 る。しか子世界の輸出㵋格点, 事變以來すでに平均し て $38 \%$ 上昇究示したといわれる。このことは割高 故に輸出学阻害されてい゙たが輸出貿易にとつては大 きなプラスである。おな米國の軍需物資原料買付けが 主に車南アジア地域に向けられているとめ, 同地域に は漸くドル不足が解消しつつある。ニューヨークタイ、 ムス紙はその額学約 10 億弗と報じている。わが輸出 市場をる罰南アジア地域に特いてドル不足が解消し， 購買力が増大してくれば，このう面へのわが輸出保伸 展しゆくとみてよい。すいに緎維品輸出には，これが 影響が現實にててさた。これに加えて邦船の航路が擴 大されつつ安る情勢に岕るから運貨の輕減も手傳い, 輸出の好挀は一應約束され\%とみてよい。

可顔，それには原料輸入が圓滑に行われることが肝 要で岕る。政府が原料不足に對じ適切な方策をとるこ ととなれば，右に指摘した好枌料の影響で，わが輸出 は今後伸展してゆくものとみて大過ない。

以上三つの好材料学交杜とし，それに附加するに國 内購買力马増加してくる。刨ら國警踭備隊，海上保安 隊の増強は200億圓の预算を马つて行われる。さらに9 月方らは供米代金の撒布がある。它の金額心 1,500 億 圓と推定される。昨年の供米代金支出は約 1,200 億囯 であつたから，今年心 300 億圓の增大となる。その 上，今年徒昨年よりも農村の金詰りがひどい。そこで 當然，供米代金の5ち，㙊業協同組合に預金として預 けられる割合は低いと思われる。それだけ通貨が消費 により多く向けられるから，通貨發行高は多くならざ るをえないのである。かくみると國内の有效需要は增

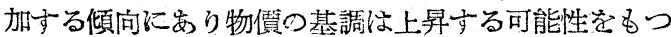

ている。ゲが物數水準が暴滕し，再びインフレへの逆 轉はないであろう。物價も急騰ではなくて漸騰であ る。なぜか。

その第一の理由は，特需の買付けは弗拂いであり弗 の裏付けがあるから苂。インフレは物の襄付けのない 通貨が増發されて，物と金との均衡が破壞されるとこ ろから起る。しかるに今度の特需は弗で支拂われる。 從つてこの弗をるつて物資の輸入が出來るのである。 勿袷, 既に述べた如く, 重要物資の不足が世界的に起 り，各國が買海りとなるであろ5から，輸入が圆滑に 行われるかどうかは甚だ疑問がある。從つて特需買上 げとそれが原料輸大との間の，タイムラッグから，物 價の上陹が速められることば女ろ 5 が，これ学長い甘 てみれば，弗資金の獲得心必ず原料輸入の増加学盾ら し，金と物との均衡は恢復されてくる篦である。決し て物資不足からインフレ再然となるものではい。

第二の理由は，税金關係から通貨の吸上げが行わ れ，これに關連して政府の資金操作も，インフレ抑制 を目指して強行されてくる。まを金融面加らす調整が 岁る。從來とても，財政的に通貨の收縮しすぎる傾向 が見えれば，貸出増加をほかつて金融学緩和し通貨量 を請整してきた。財政面で支出超過となれば，金融面 で貸出回收の強化と貸出制限で操作してきた。從つて インフレ再撜の傾向が現れてくれば，當然，金融面の 操作が働いてくる。思惑的な資金供給心嚴重に抑制さ れよ5。

第三の理由は，食料不安のないこと究。終戰直啳の インフレ急進には食生活の不安からきた買漁りが大き な原因となつたことは否定できない。於が今後心國民 の食生活安定は約束されている。今年的米も豊作とい 5。气れに政府の手持主食は龙大な額に上つている。 現在 1,936 萬石の主食を蓄えている。4 ケ月分の配給 量に相當与る。それに本年度の輸入計畫量と最近の極 東情勢にそなえて，更に追加輸入をも考え，手持量の

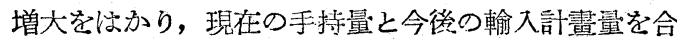
算すれば，9 ケ月分の配粭は充分賄える計算になる。 國民の食生活の安泰保保登されている譯厄從つて食不 安からくる人心の動摇，インフレ促進はありえない。

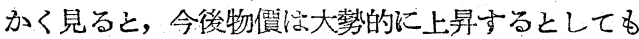
インフレ化する懸念岕ない譯だ。要するに特需關係で 局剖的な物望上具や，タイムラッグによる物價高にあ

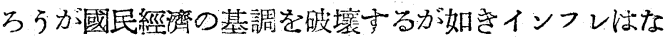
い。景氣は本格的に立淔るとい5結論になり，その時 期は來春頃とみるのが妥當である。( 9 月 18 日) 
諒解を頂くよう邁絡のこと)

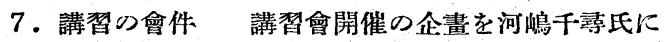
依賴してあつたが候補地（滋賀縣信樂）乙交涉中で 具體案が出來ず次回に繰延べる

8. 創立 60 周年記念儿關する件 來年 10 月が本 會創立 60 年に當るので擧行すべき記念事業につい て龜, 高橋兩企畫理事に立案を願らことにした。

9. 案業工學便覽改訂出版の件改言出版問題にン き山内理事より, 經過報告があり協議の結果, 協會 自體の出版はゃらず，丸善或は小鋕工業出版社等に 更に交涉してみることにした。

10. 次回理事會 (學術會議會員候補者決定凹䈍) は7 月 31 日，午前 10 時より開催する。

\section{日本學術會議會員候補者選考委員會並に臨時理事會} 去る7月 31 日午前 10 時より東京地學協會で徳根會

長, 加藤, 熊谷, 山内, 若林各理事, 選考委員河島 野口, 森谷, 山口 (悟郎)，山口 (太郎) (委任狀 8 通)の5 氏出席のもとに，日本學術會議委員候補者推 茜について各支部に照會の結果，關東支部より永少彰
一郎, 山内俊吉兩氏 (全國區, 地方區の別は選考委員

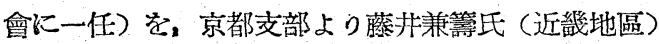
を推簏してきたがその他はなかつた。

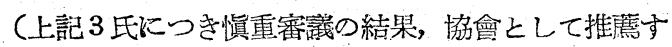
べき候補者とその立候補地區を次の如く決定。

全國區永井彰一郎, 關車地區 山内 俊吉, 近畿地區 藤井 兼籌 (節退)

全國區候補者（永井氏）は日本化學會と連携して推 蔍すべき候補者として申入れをする。但しその結果の 如何に拘らず本會としてては前記の通り推鹤する。

編集委員會 8 月 18 日午啳 2 時卅より, 横濱市 鶴見區の旭硝子株式會社研湥所で, 吉木理事, 山田, 川久保，山口の 3 委䝿出席のもとに開き 11 月號編集 に關し協議した。揭載論文次の通りと決定。

○陶磁器用石膏型比關主る研究第 2 報 (河島千尋・ 奥田進）○不消化性ドロマイト質耐火物の政究第 2

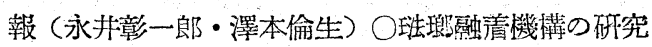
第7 報 (田代仁)

\section{中ダルは續くか}

商品界す株式界も 8 月下旬加 9 月にかけて, 中ダルミ現像を呈している。この中ダルミ活今後

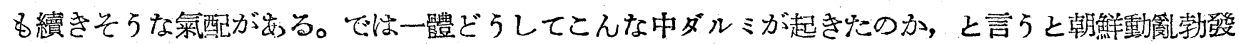
後の商品にしろ株式にしろ, 先高見越といらか, 一種の思惑で價格滕貴が行過ぎをため, その修正 運動が起きているからである。もちろん經濟界の實勢は好轉してをり，その底流燋りはない。そ の基調は世界的軍撗ブーム艺背景にしているだけ根強いるのが岕る。しかし乍らその世界的軍撗景 氣が本物の景氣となつて經濟界に浸潤するには時がかかるのである。第一次及び第二次世界大疃の 場合でる，軍擴景氣が本格化するまでに，1年なり 2 年かかつている。朝鮮動亂を契機比て軍

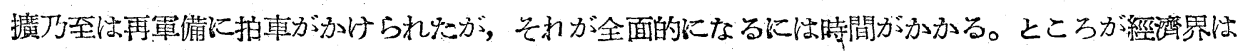
生き物であるから先を見越す作用が岁り，一眭的には物價でも株價でも行過ぎるものである。こと

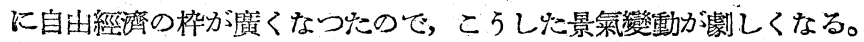

第二には金詰りの深刻化である。朝鮮事變以來國民の一部に思惑に走る者が岀り，今後特需資金 や供米代金の放出が増加寸ると，インフレ再然の伦險がある。そこで政府はこれが抑制策として， 暴利取締令を出したり，勸告價格穵命じたりしたが，さらに日銀は市中銀行に對して貸出抑制のう 針をとつ誌。他方税金攻勢は 9 月から高李つてきたので，金詰りは一層深刻となつたので㐫る。そ こで商品も株式も買いたいが，金がないから買えないのみならず，手持を賣つて資金の裕りを作る 必要さえある。

以上のごとさ先高見越の修正と，金詰りが物價や株價の中ダルミ学起しているのである。財界の

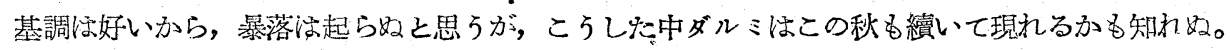
そらして來年の春頃にでもなると，本格的な軍擴（特需を含めて）ブームが出ると觀測せられる。 